\title{
Belajar dari Rumah selama Pandemi COVID-19: Risiko Ledakan Kasus Miopia pada Anak Usia Sekolah
}

\author{
Carennia Paramita ${ }^{1}$, Elcha Leonard ${ }^{2}$ \\ ${ }^{1}$ Rumah Sakit Umum Daerah Arga Makmur, Bengkulu Utara, Indonesia \\ ${ }^{2}$ Rumah Sakit Umum Imanuel Sumba, Sumba Timur, Indonesia \\ Penulis Korespondensi: carennia.paramita@gmail.com
}

\begin{abstract}
Abstrak
Miopia adalah kelainan refraksi dengan prevalensi kasus tertinggi secara global terutama pada anak usia sekolah. Dalam jangka panjang, miopia dapat meningkatkan risiko gangguan visus permanen dan memengaruhi kualitas hidup anak di masa dewasa sehingga perlu mendapat perhatian khusus. Selama pandemi COVID-19, pemerintah telah menetapkan pembatasan kegiatan masyarakat, salah satunya dengan memberlakukan kebijakan belajar dari rumah bagi anak usia sekolah. Kegiatan belajar dari rumah tentu akan meningkatkan penggunaan gawai pada anak serta mengurangi pajanan anak terhadap sinar matahari alami sehingga berkaitan erat dengan peningkatan kasus miopia. Padahal, lamanya anak melakukan aktivitas di luar rumah berperan dalam membatasi pertambahan elongasi aksial bola mata dan perubahan miopia dalam refraksi. Sebaliknya, aktivitas jarak dekat serta paparan terhadap gawai secara intens dapat meningkatkan kondisi asthenopia dan berisiko menimbulkan ledakan kasus miopia. Masalah ini dapat menambah beban peningkatan kasus miopia terutama di masa pandemi COVID-19 yang belum dapat diketahui akhirnya. Oleh karena itu, diperlukan langkah pencegahan miopia selama masa pandemi yang tepat dan efektif. Hal tersebut menjadi fokus pembahasan telaah pustaka ini. Para orang tua, guru, tenaga kesehatan, dan pemerintah harus bersama-sama mempromosikan gaya hidup sehat serta mewujudkan upaya pencegahan miopia pada anak usia sekolah.
\end{abstract}

Kata kunci: anak usia sekolah, COVID-19, miopia

\section{School from Home during the COVID-19 Pandemic: Risk for a Further Myopia Boom in School-Aged Children}

\begin{abstract}
Myopia is a refractive disorder with the highest prevalence found among school-aged children globally. In a long term, myopia may increase the risk of having permanent vision loss which affects the quality of life. Hence, myopia is considered a serious concern particularly during COVID-19 pandemic. The government has introduced public activity restriction enforcement, one of which is by enacting school at home for children in the hopes of slowing transmission rates. Unfortunately, this policy contributes to increasing gadget usage and lack of natural light exposure to children. This issue is closely related to the rise of myopia cases among school-aged children because of inadequate exposure to natural light. It is known that playing outdoors inhibits the axial length elongation and myopia changes. On the contrary, near activities and intensive screen time exposure induce asthenopia, thus, risking a myopia boom. Accurate and effective steps of myopia prevention for school-aged children during COVID-19 pandemic are the merit of this paper. Parents, teachers, medical practitioners, and the government need to work hand in hand in promoting healthy lifestyle and preventing myopia in school-aged children.
\end{abstract}

Keywords: COVID-19, myopia, school-aged children

How to Cite :

Paramita C, Leonard E, Belajar dari Rumah selama Pandemi COVID-19: Risiko Ledakan Kasus Miopia pada Anak Usia Sekolah. J Kdokt Meditek. 2021;27(2): 183-189. Available from: http://ejournal.ukrida.ac.id/ojs/index.php/Meditek/article/view/2062

https://doi.org/10.36452/jkdoktmeditek.v27i2.2062 


\section{Pendahuluan}

Miopia adalah kondisi kelainan okular yang umum ditemukan pada usia anak. Anak dengan miopia akan menghadapi beban fisik dan finansial untuk memakai kacamata atau lensa kontak semasa hidupnya. Perlunya koreksi optik pada anak dengan miopia di masa yang akan datang dapat memengaruhi aktivitas sosial dan pemilihan karir pada anak yang beranjak dewasa. Anak dengan kelainan miopia derajat tinggi yang disertai dengan kondisi patologis juga berkaitan dengan peningkatan risiko terhadap gangguan visus permanen. ${ }^{1}$

Prevalensi miopia terus meningkat dan telah menjadi isu penting dalam kesehatan masyarakat. Di Taiwan dan Singapura, prevalensi miopia adalah sebesar 20\%-30\% pada anak usia 6-7 tahun dan meningkat sampai $84 \%$ pada siswa sekolah setara sekolah menengah atas di Taiwan., ${ }^{2,3}$ Di Singapura, peningkatan aktivitas dekat pada anak terbukti meningkatkan panjang aksial bola mata sebesar $0,17 \mathrm{~mm}$ yang nantinya menjadi salah satu faktor risiko anak mengalami miopia tinggi. ${ }^{3}$ Progresivitas miopia pada anak di Asia Timur sangat tinggi (sekitar 1 dioptri per tahun) dan sekitar $24 \%$ dari populasi miopia tersebut berkembang menjadi pasien dengan miopia tinggi ketika mencapai usia dewasa. ${ }^{4}$

Progresivitas miopia ini diduga akan semakin bertambah pesat seiring dengan perkembangan zaman di mana kebutuhan untuk memakai gawai dan melakukan aktivitas jarak dekat lainnya pada anak dalam menyelesaikan aktivitas sehari-hari semakin tinggi. Selain itu, hal ini didukung dengan adanya peraturan oleh pemerintah Indonesia untuk melakukan kegiatan belajar dari rumah pada anak sehubungan dengan peningkatan insidensi Corona Virus Disease 2019 (COVID-19). Munculnya COVID-19 terjadi dan dimulai pada bulan Desember 2019 di Wuhan, Provinsi Hubei, China yang selanjutnya menyebar ke seluruh dunia. Penyakit COVID-19 merupakan penyakit infeksi saluran pernapasan yang disebabkan oleh severe acute respiratory syndrome coronavirus 2 (SARS$\mathrm{CoV}-2$ ) yang angka kejadiannya terus mengalami peningkatan oleh karena tingkat virulensinya yang tinggi. Terhitung sejak bulan Februari 2020, World Health Organization (WHO) telah menetapkan COVID-19 menjadi permasalahan pandemi di dunia. Hal ini tentu menjadi suatu tantangan baru terhadap seluruh bidang kesehatan di dunia untuk menghadapinya. ${ }^{5,6}$
Dampak yang terjadi akibat masa karantina telah dirasakan oleh berbagai pihak. Anak-anak usia sekolah yang berkisar antara 6-18 tahun merupakan salah satu golongan yang rentan mengingat mereka harus menjalankan proses belajar dari rumahlewat internet (dalam jaringan/daring). Padahal, lamanya anak menggunakan gawai seperti ponsel, komputer tablet, dan laptop berpengaruh terhadap ketajaman penglihatan yang mereka miliki. Indonesia memberlakukan peraturan untuk melakukan pembelajaran dari rumah sejak tanggal 18 Mei 2020 sebagaimana tercantum dalam Surat Edaran Nomor 15 Tahun 2020 tentang Pedoman Penyelenggaraan Belajar dari Rumah dalam Masa Darurat Penyebaran COVID-19. ${ }^{7}$

Oleh karena itu, telaah pustaka ini bertujuan untuk meningkatkan kewaspadaan bagi para pembaca agar memberi jarak dan batas waktu menatap layar digital serta memberikan saran yang dapat diaplikasikan saat anak belajar di rumah agar peningkatan progresivitas miopia dalam masa pandemi COVID-19 dapat dicegah.

Seiring dengan perkembangan kasus pandemi COVID-19 di seluruh negara di dunia, muncul kebijakan dari pemerintah untuk membatasi penyebaran kasus COVID-19. Kebijakan yang dikeluarkan pemerintah di antaranya adalah pembatasan bepergian baik mancanegara maupun domestik dan mencegah perkumpulan yang melibatkan orang banyak seperti menerapkan jam aktif bagi tempat aktivitas sosial masyarakat seperti pusat perbelanjaan, bekerja dari rumah (work from home), dan sekolah dari rumah (school from home). ${ }^{8}$ Dampak langsung dari virus corona terhadap gejala pada sistem respirasi memang telah banyak diketahui sehingga menyita perhatian dan telah menjadi fokus utama dalam penanganan virus ini. Namun, ternyata dampak tidak langsung terhadap kesehatan yang dapat terjadi akibat pandemi COVID-19 tidak dapat diabaikan.

\section{Definisi Miopia pada Anak}

Perkembangan normal mata pada neonatus dan bayi adalah mengalami hiperopia sebesar +2 dioptri yang akan menurun secara cepat menuju +1 dioptri selama usia 2 tahun pertama. Pada usia 2 sampai 14 tahun, hiperopia perlahan-lahan berkurang dan menjadi emetropia. Bola mata akan mengalami perkembangan dari panjang aksial 18 $\mathrm{mm}$ setelah lahir menjadi $23 \mathrm{~mm}$ saat usia 3 tahun dan mencapai rata-rata $24 \mathrm{~mm}$ saat dewasa, sehingga hanya ada kesempatan pertambahan 
sebesar $1 \mathrm{~mm}$ pada usia 3 sampai 13 tahun. $^{4}$ Peningkatan panjang aksial $1 \mathrm{~mm}$ akan berkaitan dengan pergeseran miopia sebesar -2 sampai $-2,5$ dioptri yang dikompensasi dengan pendataran kornea dan penipisan lensa. ${ }^{9}$

Salah satu klasifikasi miopia secara umum adalah miopia non-patologis dan miopia patologis. Keduanya diklasifikasikan berdasarkan koreksi refraksi yang dibutuhkan. Miopia non-patologis atau miopia simpleks tidak disertai dengan perubahan retina, dapat kembali memiliki penglihatan normal dengan menggunakan kacamata atau lensa kontak yang ukurannya sesuai, dan biasanya ringan (kurang dari $-3,00$ dioptri); atau miopia sedang $(-3,00$ hingga $-6,00$ dioptri). Di sisi lain, miopia yang bersifat patologis merupakan miopia dengan gangguan refraksi tinggi yang dapat membahayakan makula dan berakhir pada hilangnya penglihatan. Miopia patologis biasanya berukuran lebih dari $-6,00$ dioptri atau panjang aksial bola mata lebih dari 26,5 mm. Miopia patologis di kemudian hari dapat menjadikan seseorang berisiko tinggi mengalami hilangnya penglihatan oleh karena lepasnya retina, neovaskularisasi koroid, katarak, glaukoma, dan atrofi makula. ${ }^{4,10,11}$

Miopia merupakan salah satu kelainan okular yang paling umum terjadi pada masa anak dan dapat dicegah sebelum menjadi penyebab hilangnya penglihatan. ${ }^{12,13}$ Peningkatan risiko ledakan kasus miopia pada anak usia sekolah (myopia boom) secara khusus banyak terjadi di Asia. Di negara Asia Timur, prevalensi miopia pada dewasa usia muda sudah mencapai $80 \%-90 \%$ , di mana lebih dari 20\%-nya memiliki miopia tinggi (lebih dari $-5,00$ dioptri hingga $-6,00$ dioptri).,14 Hal ini diakibatkan oleh karena tingginya tuntutan pendidikan pada anak di negaranegara Asia dan meningkatnya kecanggihan teknologi secara sangat cepat yang digunakan oleh anak-anak. Orang tua dianjurkan untuk membawa anaknya ke dokter mata agar dapat dilakukan penapisan awal (screening) kelainan mata sejak anak usia $<6$ tahun (sebelum masuk sekolah) walaupun tanpa keluhan pada mata. Penapisan awal juga bisa dilakukan sejak anak berusia 2,5 atau 3 tahun sepanjang anak kooperatif. Dalam pemeriksaan mata, pendekatan objektif dan penggunaan tetes mata sikloplegik dapat digunakan untuk mengurangi akomodasi yang sangat kuat pada mata anak.

\section{Hubungan Peningkatan Screen Time Selama Pandemi COVID-19 dengan Miopia}

Saat masa pandemi COVID-19, terdapat peningkatan prevalensi miopia di banyak negara di seluruh dunia yang memang sebenarnya telah lama menjadi masalah epidemi secara global. Menurut UNESCO, lebih dari 160 negara telah menerapkan belajar dari rumah sebagai usaha untuk membatasi penyebaran COVID-19 yang meliputi sekitar 87\% populasi pelajar di seluruh dunia. Sebagai konsekuensinya, hal ini dapat menyebabkan perkembangan dan memperberat kejadian miopia. Sampai saat ini, belum ada standar yang baku dalam menentukan durasi antara pajanan layar (screen time) terhadap mata. Oleh karena itu, masih sulit untuk memperkirakan secara pasti efek lama pajanan terhadap fungsi refraktif. ${ }^{8}$

Kementerian Pendidikan dan Kebudayaan Republik Indonesia melalui Surat Edaran Nomor 15 Tahun 2020 menetapkan untuk para peserta didik belajar dari rumah selama darurat penyebaran COVID-19. Hal ini dilaksanakan dengan tetap memperhatikan protokol penanganan COVID-19. Belajar dari rumah dilakukan melalui pembelajaran jarak jauh daring dan/atau luar jaringan (luring) dilaksanakan sesuai dengan pedoman penyelenggaraan belajar dari rumah. ${ }^{7}$ Walaupun surat edaran tersebut bertujuan untuk mengontrol penyebaran COVID-19, keresahan terhadap bertambahnya risiko anak mengalami miopia menjadi muncul karena berkurangnya waktu untuk melakukan aktivitas di luar dan bertambahnya waktu untuk berhadapan dengan layar digital karena anak mencari hiburan di televisi dan media sosial yang tidak baik bagi kesehatan mata.

Studi oleh Ganne dkk (2020) melaporkan peningkatan pajanan screen time selama 6 jam atau lebih dapat meningkatkan kejadian miopia hingga tujuh kali lipat pada anak yang mengikuti kelas daring selama pandemi jika dibandingkan dengan sebelum pandemi $(57,01 \%$ versus $10,9 \%)$. Mayoritas anak-anak menggunakan gawai dalam jarak 20-37 cm. ${ }^{15}$ Studi oleh Pietrobelli di Italia dan Bahkir di India memperlihatkan peningkatan penggunaan gawai hingga 4-5 jam per hari pada anak-anak dan remaja selama masa karantina di rumah karena pandemi COVID-19 mengharuskan mereka untuk mengikuti kegiatan belajar (kelas daring, tugas, dan webinar). ${ }^{16,17}$ Oleh karena orang dewasa juga bekerja dari rumah, gawai menjadi alat yang berguna untuk menemani anak-anak ketika orang tua bekerja. ${ }^{18}$ Meta-analisis oleh 
Huang dkk (2015) yang melakukan pengkajian terhadap 12 studi kohort, 15 studi potong lintang, dan memiliki jumlah subjek sebesar 25.025 anak usia 6-18 tahun telah menyarankan anak-anak untuk mengurangi aktivitas jarak dekat untuk menurunkan risiko rabun jauh atau miopia di kemudian hari. ${ }^{19}$ Aktivitas jarak dekat yang dimaksud adalah kegiatan seperti membaca, belajar, menulis, mengerjakan pekerjaan rumah, menonton televisi, dan bermain video games.

Selain miopia, Ganne dkk (2020) juga menyatakan anak-anak yang mengikuti kelas daring lebih berisiko mengalami kelelahan pada otot mata (asthenopia). Computer vision syndrome atau masalah pada kesehatan mata yang disebabkan oleh aktivitas berlebihan karena terlalu lama menatap layar gawai, ditemukan terbanyak pada anak usia sekolah yang mengikuti kelas daring ( $\mathrm{p}<0,0001)$, lebih lama terpajan layar gawai $(\mathrm{p}<0,0001)$, jarak $<20 \mathrm{~cm}(\mathrm{p}=0,002)$, anak-anak yang menggunakan gawai pada kondisi gelap $(\mathrm{p}=$ $0,017)$, dan pada anak-anak yang jarang atau tidak mengambil waktu istirahat $(\mathrm{p}=0,018) .{ }^{15}$

Studi oleh Picotti dkk (2021) menunjukkan bahwa progresivitas kasus miopia meningkat secara signifikan dari tahun 2019 sampai 2020, periode di mana terjadi kondisi anak dirumahkan, dibandingkan dengan periode tahun 2018-2019. ${ }^{12}$ Selama periode tahun 2019-2020, anak berada dalam kondisi lockdown karena kondisi homeschooling dan tinggal di rumah setelah kebijakan pemerintah dilaksanakan. Pajanan waktu yang lama bagi anak untuk bermain di luar dapat membatasi pertambahan elongasi aksial bola mata dan perubahan miopia dalam refraksi. ${ }^{12}$ Kondisi diam di rumah berkepanjangan juga dapat meningkatkan kemungkinan terpapar kondisi aktivitas jarak dekat dalam bentuk membaca dan peningkatan screen time seiring dengan reduksi paparan cahaya matahari dan kejadian aktivitas di luar ruangan. ${ }^{20,21}$

Studi potong lintang oleh Wang dkk (2015) di Cina melaporkan prevalensi terjadinya miopia pada tahun 2020 meningkat sebanyak 3 kali lipat pada anak usia 6 tahun, 2 kali lipat pada anak usia 7 tahun dan 1,4 kali lipat pada anak usia 8 tahun. Namun, peningkatan ini tidak terlihat pada anak di kelompok usia yang lebih tua (9-13 tahun) walaupun anak pada usia tersebut (kelas 3 sampai 6) menjalankan pembelajaran daring lebih intensif (2,5 jam) dibandingkan kelompok anak kelas 1 dan 2 (1 jam per hari) ${ }^{22}$ Hal ini mengarah pada suatu hipotesis bahwa anak dengan usia lebih kecil akan menjadi lebih sensitif terhadap adanya perubahan lingkungan dibandingkan dengan anak yang usianya lebih besar. Usia 6-8 tahun merupakan periode penting untuk perkembangan miopia. Dalam rentang usia ini, plastisitas miopia masih tinggi sehingga untuk mengontrol miopia lebih mudah jika dibandingkan dengan kelompok anak berusia lebih dari 8 tahun. ${ }^{22}$ Meta-analisis yang dilakukan oleh Holden dkk (2020) memprediksi akan terjadi peningkatan prevalensi miopia dua kali lipat dan tujuh kali lipat risiko kehilangan penglihatan yang disebabkan oleh miopia pada tahun $2050 .{ }^{23}$ Prediksi ini dapat terjadi lebih cepat jika tidak dilakukan langkah nyata pada masa pandemi COVID-19.

\section{Pencegahan Progresivitas Miopia pada Anak Usia Sekolah di Masa Pandemi Covid-19}

Peningkatan penggunaan gawai berpotensi untuk menimbulkan permasalahan okular dan nonokular seperti bertambahnya miopia, asthenopia, kerusakan retina, gangguan tidur, masalah muskuloskeletal, dan kelainan perilaku. Terdapat beberapa cara yang dapat dilakukan dalam praktik sehari-hari untuk mencegah anak mengalami computer vision syndrome, antara lain menerapkan aturan '20-20-20' yang berarti mengistirahatkan mata selama 20 detik setiap melihat layar selama 20 menit, dan anak perlu melihat jarak sejauh 20 kaki (6 meter) untuk mencegah terjadinya spasme akomodatif dan asthenopia. Selain itu, diperlukan penyesuaian pencahayaan di lingkungan sekitar untuk menghindari silau, ${ }^{24}$ menjaga jarak mata dengan layar komputer $>36$ inci $(>90 \mathrm{~cm})$, jarak mata dengan layar ponsel $>40 \quad \mathrm{~cm}^{23,25}$ menempatkan layar digital $20^{\circ}$ di bawah tingkat mata, ${ }^{26}$ membatasi waktu melihat layar digital selama <4 jam/hari, dan menggunakan mode malam (night mode) setelah sore hari. ${ }^{27}$ Rekomendasi screen time yang disarankan untuk anak-anak dapat disesuaikan dengan usia selama masa belajar di rumah. Anak usia sekolah disarankan untuk berpartisipasi dalam aktivitas fisik intensitas sedang minimal selama 60 menit, waktu untuk bermain dengan gawai tidak lebih dari 2 jam, dan waktu tidur yang berkualitas sekitar 911 jam per hari. ${ }^{28,29}$ Beberapa hal lainnya yang disarankan pada anak untuk meminimalisir screen time selama masa pandemi diantaranya dengan mematikan semua layar perangkat elektronik saat makan bersama keluarga dan bepergian, melakukan pengawasan dan kontrol pada anak, menghindari penggunaan layar elektronik sebagai penenang anak atau untuk menghentikan tantrum, 
serta mematikan layar dan mengeluarkan gawai dari kamar tidur 30-60 menit sebelum waktu tidur. ${ }^{28,29}$

Aktivitas di luar rumah dan pajanan pada cahaya alamiah diketahui sebagai faktor protektif terhadap onset dan progresivitas miopia. Dengan adanya kondisi lockdown dan kurangnya pajanan aktivitas di luar rumah, sangat diperlukan cara yang inovatif untuk dapat menjaga pajanan cahaya matahari yang cukup pada anak. Anak dapat menghabiskan kurang lebih 1 jam per hari dengan memanfaatkan area sekeliling rumah seperti teras, balkon, dan kebun di mana tingkat cahaya cukup tinggi dibandingkan dengan lingkungan di dalam rumah. Orang tua dapat didorong untuk menghabiskan waktu keluarga di siang hari yang melibatkan anak setidaknya menghabiskan waktu di teras, balkon, atau melibatkan anak dalam kegiatan aerobik untuk menjaga ketertarikan anak. ${ }^{30}$ Menjaga atau meningkatkan aktivitas fisik pada anak yang merupakan golongan rentan terinfeksi COVID-19 justru dapat menurunkan risiko mereka mengalami infeksi pada sistem respirasi. ${ }^{28}$ Saat anak melakukan pembelajaran daring, batasi duduk yang terlalu lama. Setiap 3060 menit duduk, harus diselingi dengan berdiri dan melakukan peregangan selama 1 menit.

Edukasi terhadap anak, orang tua, serta guru mengenai rekomendasi yang perlu diterapkan selama masa pandemi adalah sebuah hal yang penting. Perlu ditekankan pentingnya pencegahan bagi anak yang memiliki risiko miopia, seperti adanya riwayat miopia yang ditemukan pada salah satu atau kedua orang tua dan juga anak yang memiliki beban akademik tinggi di sekolah. ${ }^{30}$ Anak perlu secara aktif dilibatkan dalam aktivitas bermain di luar dibandingkan dengan permainan digital yang dapat diakses dengan mudah saat memiliki waktu luang. Aktivitas bermain di luar dapat memanfaatkan area sekitar rumah seperti teras atau balkon yang terkena cahaya matahari minimal satu jam dalam sehari. Orang tua dan guru juga dituntut untuk kreatif dalam memodifikasi cara belajar anak selain melalui daring, misalnya seperti melakukan pemberian tugas dengan melakukan perekaman mandiri, membatasi materi lewat tatap layar, dan berbagai aktivitas sejenis lainnya.

Di sisi lain, para tenaga kesehatan perlu memahami dan merekomendasikan gaya hidup sehat ke orang tua, anggota rumah, dan pengasuh anak dengan tetap menyesuaikan protokol kesehatan. Pemerintah dapat mengambil peran dalam mempromosikan gaya hidup sehat ini kepada anak-anak dengan cara bekerja sama dengan orang-orang yang berpengaruh atau media untuk secara rutin mempromosikan perlunya aktivitas fisik dan pembatasan duduk yang terlalu lama.

\section{Penutup}

Pandemi COVID-19 mengharuskan anak untuk mengikuti program belajar dari rumah secara daring melalui layar gawai. Kegiatan anak di luar menjadi terbatas oleh karena masa karantina yang harus dijalankan selama pandemi. Secara tidak langsung, aktivitas jarak dekat serta kurangnya paparan sinar matahari alamiah meningkatkan kondisi asthenopia dan pertambahan kasus miopia untuk anak. Jika tidak ditanggulangi sejak dini, hal ini berisiko menjadi ledakan kasus miopia, padahal, masa pandemi COVID-19 belum dapat diketahui akhirnya. Oleh karena itu, diperlukan langkah pencegahan miopia selama masa pandemi yang tepat dan efektif. Para orang tua, guru, tenaga kesehatan, dan pemerintah harus bekerja sama mempromosikan gaya hidup sehat serta mewujudkan upaya pencegahan miopia pada anak usia sekolah.

\section{Daftar Pustaka}

1. Fan DSP, Lam DSC, Lam RF, Lau JTF, Chong KS, Cheung EYY, et al. Prevalence, incidence, and progression of myopia of school children in Hong Kong. Investig Ophthalmol Vis Sci. 2004;45(4):1071-5.

2. Lin L, Shih Y, Hsiao C, Chen C, Lee L, Hung P. Epidemiologic study of the prevalence and severity of myopia among schoolchildren in Taiwan in 2000. J Formos Med Assoc. 2001;100(10):684-91.

3. Saw SM, Carkeet A, Chia KS, Stone RA, Tan DTH. Component dependent risk factors for ocular parameters in Singapore Chinese children. 2002;109(11):2065-71.

4. Wu PC, Huang HM, Yu HJ, Fang PC, Chen CT. Epidemiology of myopia. Asia-Pacific $\mathrm{J}$ Ophthalmol. 2016;5(6):386-93.

5. Parrish RK, Stewart MW, Powers SLD. Ophthalmologists are more than eye doctorsin memoriam Li Wenliang. Am J Ophthalmol. 2020;A1-2.

6. World Health Organization. WHO DirectorGeneral's opening remarks at the media briefing on COVID-19 - 11 March 2020 
[Internet]. WHO. 2020 [cited 2021 Mar 6]. Available from: https://www.who.int/directorgeneral/speeches/detail/who-director-generals-opening-remarks-at-the-media-briefing-oncovid-19---11-march-2020

7. Kementerian Pendidikan dan Kebudayaan RI. Surat Edaran Nomor 15 Tahun 2020 tentang Pedoman penyelenggaraan belajar dari rumah dalam masa darurat penyebaran corona virus disease (COVID-19). 2020. [cited 2021 Mar 6]. Available from: http://kemdikbud.go.id/main/?lang=id

8. Pellegrini M, Bernabei F, Scorcia V, Giannaccare G. May home confinement during the COVID-19 outbreak worsen the global burden of myopia? Graefe's Arch Clin Exp Ophthalmol. 2020;258(9):2069-70.

9. Meng W, Butterworth J, Malecaze F, Calvas P. Axial length of myopia: a review of current research. Ophthalmologica. 2011;225(3):12734.

10. Guggenheim JA, McMahon G, Northstone K, Mandel Y, Kaiserman I, Stone RA, et al. Birth order and myopia. Ophthalmic Epidemiol. 2013;20(6):375-84.

11. Iancu G, Coviltir V, Iancu R, Corbu C. Particularities of myopia in pregnancy. Gineco.eu. 2013;9(4):196-9.

12. Picotti C, Sanchez V, Fernandez Irigaray L, Morgan IG, Iribarren R. Myopia progression in children during COVID-19 home confinement in Argentina. SSRN Electron J. 2021;5-6.

13. Saxena R, Vashist P, Tandon R, Pandey RM, Bhardawaj A, Gupta V, et al. Incidence and progression of myopia and associated factors in urban school children in Delhi: The North India Myopia Study (NIM Study). PLoS One. 2017;12(12):1-12.

14. Wu JF, Bi HS, Wang SM, Hu YY, Wu H, Sun $\mathrm{W}$, et al. Refractive error, visual acuity and causes of vision loss in children in Shandong, China. The Shandong children eye study. PLoS One. 2013;8(12).

15. Ganne P, Najeeb S, Chaitanya G, Sharma A, Krishnappa NC. Digital eye strain epidemic amid COVID-19 pandemic-a cross-sectional survey. Ophthalmic Epidemiol. 2020:1-8.

16. Bahkir FA, Grandee SS. Impact of the COVID-19 lockdown on digital device-related ocular health. Indian J Ophthalmol. 2020;68:2378-83.

17. Pietrobelli A, Pecoraro L, Ferruzzi A, Heo M, Faith M, Zoller T, et al. Effects of COVID-19 lockdown on lifestyle behaviors in children with obesity living in Verona, Italy: a longitudinal study. Obesity. 2020;28(8):13825.

18. López-Bueno R, López-Sánchez GF, Casajús JA, Calatayud J, Tully MA, Smith L. Potential health-related behaviors for pre-school and school-aged children during COVID-19 lockdown: a narrative review. Prev Med (Baltim). 2021;143:106349.

19. Huang HM, Chang DST, Wu PC. The association between near work activities and myopia in children - a systematic review and meta-analysis. PLoS One. 2015;10(10):1-15.

20. Sathyan S. Quarantine myopia: revisiting myopia control strategies during COVID-19 pandemic. Kerala J Ophthalmol. 2020;32:199200.

21. Wong CW, Tsai A, Jonas JB, Ohno-Matsui K, Chen J, Ang $M$, et al. Digital screen time during the COVID-19 pandemic: risk for a further myopia boom? Am J Ophthalmol. 2021;223:333-7.

22. Wang J, Li Y, Musch DC, Wei N, Qi X, Ding $\mathrm{G}$, et al. Progression of myopia in school-aged children after COVID-19 home confinement. JAMA Ophthalmol. 2021:1-8.

23. Holden BA, Fricke TR, Wilson DA, Jong M, Naidoo KS, Sankaridurg $P$, et al. Global prevalence of myopia and high myopia and temporal trends from 2000 through 2050. Ophthalmology. 2016;123(5):1036-42.

24. Borhany T, Shahid E, Siddique WA, Ali H. Musculoskeletal problems in frequent computer and internet users. J Fam Med Prim Care. 2018;7:337-9.

25. Shokouhi-Moqhaddam S, Khezri-Moghadam N, Javanmard Z, Sarmadi-Ansar H, Aminaee M, Shokouhi-Moqhaddam M, et al. A Study of the correlation between computer games and adolescent behavioral problems. Addict Heal. 2013;5(1-2):43-50.

26. Leung TW, Li RWH, Kee CS. Blue-light filtering spectacle lenses: optical and clinical performances. PLoS One. 2017;12(1):1-15.

27. Jaschinski W, Heuer H, Kylian H. Preferred position of visual displays relative to the eyes: a field study of visual strain and individual differences. Ergonomics. 1998;41(7):103449.

28. American Academy of Child and Adolescent Psychiatry. Screen time and children [Internet]. AACP. 2020 [cited 2021 Feb 21]. Available from: https://www.aacap.org/AACAP/Families_and 
_Youth/Facts_for_Families/FFF-

Guide/Children-And-Watching-TV-

054.aspx\#: :text=Between 18 and 24 months,limit activities that include screens.

29. Guan H, Okely AD, Aguilar-Farias N, del Pozo Cruz B, Draper CE, El Hamdouchi A, et al. Promoting healthy movement behaviours among children during the COVID-19 pandemic. Lancet Child Adolesc Heal. 2020;4(6):416-8.

30. Hussaindeen J, Gopalakrishnan A, Sivaraman $\mathrm{V}$, Swaminathan M. Managing the myopia epidemic and digital eye strain post COVID19 pandemic - what eye care practitioners need to know and implement? Indian J Ophthalmol. 2020;68(8):1710-2. 